CHAPTER TEN

\title{
POLYBIUS
}

\section{T. Roop}

Had previous chronicles neglected to speak in praise of History in general, it might perhaps have been necessary for me to recommend everyone to choose for study and welcome such treatises as the present, since there is no more ready corrective of conduct than knowledge of the past.

Polybius shows at the outset that he is writing with a far stronger sense of his place in a historiographical tradition than the three historians treated in the previous chapters. And he maintains that difference by continually returning to historiographical issues. At the start of book 9, for instance, he defines three types of history - genealogical history, accounts of foundations and kinship, and political or pragmatic history - each appealing to a different sort of audience, and explains why he decided to write a history of contemporary events: accounts of genealogies and foundations have been written by many others, but 'there is always some novelty in actual events which demands novel treatment, since it was not in the power of the ancients to narrate events subsequent to their own time' (9.2.4-a rare flash of Polybian wit?).

Polybius' constant dwelling on the nature of historical writing proves fruitful for the narratological analysis of time. Polybius explicitly addresses his own and other historians' handling of Genette's temporal categories. He almost seems to be writing with the narratologist in mind. His constant analysis of his method even makes up to some extent for the fragmentary state of his text (after book 5 at least). We must, however, beware of succumbing too readily to the terms set by Polybius himself. He may start by claiming that it is not necessary for him to outline the advantages of studying history-but that does not stop him from elaborating those advantages at length in the later parts of his work. That technique of false praeteritio is harmless enough. What is far more important is to uncover the ways in which Polybius' comments on his own and other historians' handling of time frequently mask the profound political bias manifest in his History. 
As with the other historians analysed above, it will be helpful to break down Polybius' treatment of time into the three aspects of frequency, speed, and order. ${ }^{1}$

\section{Frequency}

Iterative narration was sometimes used by earlier historians $(\rightarrow$ Herodotus, $\rightarrow$ Thucydides) for regular practices and for generalized descriptions of fighting. Both types of iterative narration, subsequent and omnitemporal, are also found in Polybius, ${ }^{2}$ and in his account of the First Punic War, Polybius even explains the reason for using iteration in battle narratives, or at least for certain types of fighting such as ambushes, where to write a detailed account (ta kata meros) would be impossible and in any case unprofitable (I.56.II-57.4; 7.I5.I). Polybius uses iteration to point up both a shortcoming and an advantage of narrative. The shortcoming is that an iconic narrative of a complex succession of ambushes is more or less impossible (Polybius compares the difficulty of describing all the blows in an evenly fought boxing match). The advantage is that narrative can compress the complexity of actual fighting so as to bring out the general trends that are useful for understanding the development of a war. It should be noted, however, that Polybius defends his technique in both passages using the same terminology he applies to narrative speed (kata meros; see below). That is, he treats iterative narrative as a form of summary.

The most common departures from singulative frequency are repetitions caused by Polybius' strong narratorial control. ${ }^{3}$ At the start of book 3 (after the two introductory books), he offers a summary of the whole work, at least as it was originally planned, in two pages (3.2-3), explaining that 'a previous general view is of great assistance to the mind in acquiring a knowledge of details, and at the same time a previous notion of the details helps us to knowledge of the whole' (3.r.67). He then explains why he decided to continue beyond the end he

${ }^{1}$ All dates are BC and all references are to Polybius unless otherwise stated. Translations are taken from Paton (Loeb), with some changes (some drawn from Walbank $1957^{-1979,}$ a work to which I am heavily indebted).

${ }^{2}$ Cf. e.g. $4.3^{2}$ on Messenian policy (combined with overt advice to the Messenians); 4.45 on the constant warfare between Byzantium and the neighbouring barbarians; and 6.53 on Roman funerary practice.

${ }^{3}$ Cf. Ibendorff I930: 27-30; SAGN I:I5I-152. 
had originally set for his work ( 167 ) down to 146 , and summarizes this additional period in slightly under a page (3.5). The work ends with a briefer recapitulation (39.8) and with a whole book (which does not survive) giving the periods covered by the history, the number of books, and the arithmos of the whole work. The repetition caused by summaries of the History's contents at the beginning and the end is matched by frequent recapitulations within the work itself - notably passages where Polybius marks out synchronisms, gives summaries at the start and end of the contents of separate books, ${ }^{4}$ and resumes topics from earlier in the work. When resuming his Greek narrative at the start of book 4, for instance, Polybius 'briefly recalls to the minds of my readers the sketch I gave in my second book of Greek affairs and especially of the growth of the Achaean League' (4.I.4): a one-page sketch follows that even repeats the 'fact' that the first Achaean king was Tisamenus son of Orestes. Later Polybius marks out Philip V's change for the worse with a similar repetition (7.I3.2, recalling 'a statement I made in my fifth book'). These repetitions seem to be connected with Polybius' awareness that the length of his work made it difficult to follow (3.32.I). At the same time, in the passages on the Achaean League and on Philip V Polybius' own Achaean bias is manifest: the claim that he first makes in book 5 and then repeats in book 7 is that Philip's failings were due to Demetrius, not to the Achaean statesman Aratus.

\section{Speed}

The most striking variations of speed in Polybius' History are related to temporal order. Polybius opens with two introductory books to provide the reader - especially the Greek reader, who is not expected to be familiar with the period (I.3.7-8) — with the knowledge required to follow the main story (Rome's rise to power). First he offers an eightpage summary of the period 386-264 (I.6-I2.4), leading up to what has already been defined as the start of the introduction proper, 'the occasion on which the Romans crossed the sea from Italy' (I.5.I). Then

4 The term for the initial summary is proekthesis: cf. Walbank I957-I979: I 297-298. For the first six books Polybius included prographai, lists of contents appearing either outside the scroll or inside, before the text; the only proekthesis was the general summary of the whole work at 3.2-6 (cf. ir.ra, with Walbank ad loc.). At I4.ai.i Polybius claims that the proekthesis 'arrests the attention of the reader' by showing the interconnections between events. 
he gives a brief (epi brakhu and kephalaiōōos, I.I3.I) listing of the events to be covered in the introduction (the First Punic War, Carthaginian wars in Libya and Spain, the Roman crossing to Illyria and war against the Italian Celts, and the Cleomenic War in Greece, I.I3.2-5) and a justification of the brevity of his treatment: 'to recount all these events in detail (exarithmeisthai ta kata meros) is neither incumbent on me nor would it be useful to my readers; for it is not my purpose to write their history but to mention them summarily (kephalaiōdoss) as introductory to the events which are my real theme' (I.I3.6-7). ${ }^{5}$ It is only later, when the narrative turns from Roman and Carthaginian affairs to Greece, that Polybius offers a 'not wholly convincing' ${ }^{6}$ explanation for his failure to give in the introduction a sketch of prior events in Asia and Egypt: they are said to have been covered by many historians already, and 'in our own times Fortune has wrought no such surprising change in these countries as to render any notice of their past necessary' (2.37.6). Again Polybius' Achaean interests are evident.

The summary form of books $\mathrm{I}^{-2}$ is shown when nine years of the Carthaginian war in Spain are described in sixteen lines (2.I.5-9) or when the successes of the Spartan king Cleomenes are listed (2.5I.I2). But that extreme brevity is not typical of the narrative of books I-2 (it is perhaps no accident that Polybius uses the list form for the successes of an enemy of the Achaean League). The narrative of the First Punic War covers 23 years in 67 Loeb pages (I.I6-63), with a partly annalistic arrangement (new consuls are generally noted) and some annalistic formulae (e.g. 'the Roman troops in Sicily did nothing worthy of note during the following year', I.24.8). It is followed by an even more detailed account of the Carthaginian war against the mercenaries (three years and four months in 32 pages, I.65-88); by a quicker treatment of Carthaginian fighting in Spain and Roman involvement in Illyria and against the Gauls in the years leading up to the outbreak of the Second Punic War $\left(2 . \mathrm{I}-36 ; 4^{6}\right.$ pages for $\left.23^{8-220}\right)$; and by 42 pages on Achaean affairs (2.37-71; mainly the war against the Spartan king Cleomenes, but also including a survey of Achaea that goes back to the first king).

\footnotetext{
${ }^{5}$ Polybius uses kephalaiōōos or a cognate several times elsewhere of the summary form of books I-2: cf. I.65.5; 2.I.4, I4.I (all three times with reference to the original plan: note esp. 2.I4.I, 'in order not to depart from what is proper for the introduction as defined in the preface'); 2.35.IO.

${ }_{6}$ Walbank 1957-1979: I 215 .
} 
Polybius does offer an explanation for the detail of one section of the introductory books. He promises at the outset to narrate the First Punic War 'somewhat more carefully (brakhu epimelesteron) ... since it is not easy to name any war which lasted longer, nor one which exhibited on both sides more extensive preparations, more unintermittent activities, more battles, and greater changes of fortune' (I.I3.II). Later he adds another reason for narrating the war at length (epi pleion) - that the readers should know the origins of Rome's naval power (I.20.8). Focussing as it does on continuity and length, Polybius' explanation of why he has chosen to narrate the First Punic War at greater length recalls Thucydides' $(\rightarrow)$ criteria for judging the greatness of the Peloponnesian War. The progress of the war is marked in two pauses ('this was in the fourteenth year of the war', I.4I.4; 'eighteenth year', 56.2) thought to be a sign that one of Polybius' sources, Philinus of Acragas, used an annalistic form; but also an effective reminder of the length of the war and of the combatants' extraordinary ability to maintain the war for so long. The claim about the greatness of the war is repeated at I.63.4, and there Polybius even contrasts the sort of ships used in the war with those used in the Persian and Peloponnesian Wars. The narratives of the Mercenary and Gallic Wars also close with narratorial claims about their greatness: the Mercenary War 'far excelled all wars we know of in cruelty and defiance of principle' (г.88.7), while the Gallic War was 'second to no war in history' in 'the desperation and daring of the combatants and the numbers who took part and perished in the battles' (2.35.2). By making claims generally used to magnify a historian's overall subject in relation to wars that are only part of his introductory books, Polybius underlines the even greater importance of the subject of the work proper. In the case of the Mercenary and Gallic Wars, however, the superlative claims do not justify the length of the accounts. On the contrary: the account of the Gallic invasion'summary indeed, but going back to the beginnings' (2.35.II) - is motivated by the fact that it was 'quite contemptible as regards the plan of the campaigns' (2.35.2). Polybius is writing to reassure an audience of Greeks, who 'not only in old times but more than once in my own days ... have been alarmed by the prospect of a Gaulish invasion' (2.35.9).

Polybius differentiates the opening two books from the remaining narrative in his reluctance to use digressions. When he describes the Po, he alludes to Greek tales about Phaethon as 'matter for tragedy', but 'detailed treatment (akribologian) of such things not suiting very well the character of the introduction', he promises proper mention of them 
when he finds 'a suitable occasion (kairon harmattonta)' (2.I6.I4-I5). On other occasions, too, in the introductory books Polybius indicates an omission of topics to be covered later on occasions 'more suitable' (1.36.4; 2.13.2). And at one point in the main story he notes that he is now treating in detail (kata meros) a topic mentioned in the introductory books (3.26.5). And yet the introductory books do contain digressive material - above all a detailed critique of the historian Phylarchus where Polybius' political bias is to the fore $\left(2 \cdot 5^{6}-63\right)$.

Polybius contrasts the summary narrative of the introduction with the detailed account of the main story (apodeiktike historia, 2.37.3; met' apodeixeōs exaggellein, 3.I.3). ${ }^{7}$ The fragmentary state in which Polybius' main story survives makes it hard to assess the speed of his narrative. The remains of book 8 , for instance, include a highly detailed and technical account of the Roman siege of Syracuse, two long ruse narratives, and a methodological section on the bias shown by historians when dealing with kings. These sections survive, however, as isolated set-pieces. It is hard to integrate them into a coherent analysis of narrative rhythm.

The remains of Polybius' History are at least sufficient for the ratio between books and years to be analysed. ${ }^{8}$ Polybius makes the task easier by commenting on his own practice in the preface to book 9: 'These are the principal events included in the above-mentioned Olympiad, that is in the space of four years which we see must be regarded as an Olympiad, and I shall attempt to narrate them in two books. I am not unaware that my work owing to the uniformity (to monoeides tês suntaxeoss) of its composition has a certain severity' (9.I.I). It is not totally clear, however, whether this comment refers to the principle of chronological order or to the practice of devoting two years to a book: as he goes on to talk of the different audiences to whom the three types of history are addressed (see above), it may be pragmatic history's relentless concentration on recent events that is at issue. But a norm of two years to a book is clearly stated in the preface to book I4, where Polybius has reached the I44th Olympiad (covering the years 204-20I, the end of the Second Punic War): 'as I wish to give such an account of the facts as their importance deserves, I have not comprised the events of two years in one book, as was my practice in previous cases' (I4.Ia.5). The importance of the contents demands that that book

7 Cf. Sacks i98I: I7I-I78 on these terms.

8 Cf. Walbank i972: i29 for a chart. 
and the next should be devoted to a single year each - a degree of slowdown found later for the climaxes of other significant wars (the war against Antiochus III in book 20, covering I92/I9I, and that against Perseus in book 29, covering $\mathrm{I} 69 / \mathrm{I} 68$ ). The narrative is also sometimes faster than the two-years-to-one-book principle: a whole Olympiad is covered in each of books I9, 22, 25, and 26. The narrative of the continuation (books 29-39) starts at an equally fast pace, with the first four books $\left(3^{-}-33\right)$ being devoted to a single Olympiad each, but it slows down for the climactic narrative of the Third Punic War and the disaster in Greece, with three successive books (37-39) covering a single year each.

As well as commenting on his own handling of speed, Polybius engages in polemic against the space devoted by other historians to certain events. In particular he is critical of the 'sensational' and 'tragic' treatment of the downfall of individuals and cities $\left(2.56 ; 7.7 ; 15.34^{-}\right.$ 36). ${ }^{9} \mathrm{He}$ complains that Phylarchus treated the fate of Mantineia 'with exaggeration and rhetorical elaboration' (met' auxēseōs kai diathesēos) but made no mention at all of the noble actions performed at the same time by the citizens of Megalopolis - Polybius' native city (2.6I.I-2); and he disparages historians of Hieronymus for writing at 'great length' (polun tina ... logon, 7.7.I) and historians of Agathocles for 'largely transgressing the bounds of what is essential to give coherence to the narrative'whereas he himself 'refrained from giving an exaggerated account (ton met' auxēsē̄s logon) of the story of this man' (I5.34.I, 36.I). As in Plutarch's criticisms of Herodotus, however, it is not the ratio between textual space and temporal duration that Polybius is criticising, but the relation between textual space and his notions of the eventworthy. ${ }^{10}$

The definition of different genres of history is also at stake in Polybius' criticism of the speed of other historians. The problem for historians of Hieronymus was that 'those who write narratives of particular events (hoi tas epi merous graphontes praxeis), when they have to deal

${ }^{9}$ Similar language is found in the three passages: terateuomenon, kathaper hoi tragōidiographoi at 2.56.IO; terateian, tragöidountes at 7.7.I-2; terateias, ekplēktikas peripeteias at I5.34.I, 36.2 .

${ }^{10}$ Note that criticisms of auxessis mainly concern rhetorical style - but they do bear indirectly on textual space. For other criticisms of historians' handling of speed, cf. 8.IO.I, I2.26b. 
with a subject which is circumscribed and narrow, are compelled for lack of facts to make small matters great and to devote much space to matters really not worthy of record' (7.7.6). And just as the writers of monographs may devote too much space to their topics, some writers who claim to have composed universal histories devote too little space to theirs: 'certain writers of history in my own times after giving an account of the war between Rome and Carthage in three or four columns, maintain that they write universal history ... giving a slighter sketch of it even than those who on public authority set up memoranda of occasional happenings in chronological sequence' (5.33.I-5).

\section{Order}

We have already noted Polybius' complex arrangement of his material at the start of the History: having defined the first two books as a summary treatment necessary for understanding his main topic, he also gives (in the case of the Roman crossing to Sicily) an even briefer introduction to that introduction. The handling of these different periods, each marked out by different speeds, raises the question of whether the introductory books are to be defined as analeptic to the main story or as the start of the story.

Polybius explicitly marks out the sketch of what had led to the Roman crossing to Sicily as an analepsis: 'my readers need not be surprised if, in the further course of this work, I occasionally go back in time (prosanatrekhomen tois khronois) to add some of the earlier history of the most famous states ... in order to take such a starting point as will make it clear in the sequel starting from what origins and how and when they severally reached their present position' (I.I2.8-9). At the same time, the very inclusion of the sketch makes problematic Polybius' attempt to establish a clear starting point for his story. Polybius was consciously grappling with the problem of causation that Herodotus confronted at the start of his work: after marking the Roman crossing to Sicily as 'the starting point of this book [viz. book I]' (I.5.I), he wrote that 'the actual cause of their crossing must be stated without comment (psilōs); for if I were to seek the cause of the cause and so on, my whole work would have no clear starting point' (I.5.3). But the length of the sketch (eight pages, most of it devoted to the last decade of the period 386-264) stands in some tension with Polybius' earlier statement that he would simply give the cause of the crossing to Sicily without comment 
(the sketch ends with Polybius writing that he has now given the cause of the crossing, I.I2.5).

The problem of a starting point also arises with the summary introduction that fills the first two books. At first it seems that these two books are marked out as analeptic: Polybius starts by saying that 'the date from which I propose to begin (arxei de tês pragmateias hêmin) is the I4oth Olympiad', justifying this with the claim that 'previously the doings of the world ... were held together by no unity of initiative, results, or locality; but ever since this date history has been an organic whole (sōmatoeidè ') (I.3.I-4). That is, Polybius is implying that the story proper only begins in book 3. But later he calls the first Roman crossing to Sicily not just the 'starting point' of book I (I.5.I) but also 'the most suitable starting point of this whole work' (oikeiotatēn krinantes arkhēn einai tēs holēs protheseōs): 'I have therefore made it my serious base, but went also somewhat further back in order to leave no possible obscurity in my statements of general causes' (I.I2.5-6, ringing with I.5.I). The two beginnings are further justified by the fact that they coincide with the endings of the works of two earlier historians - Timaeus for the first crossing to Sicily (I.5.I; 39.8.4) and Aratus of Sicyon for the I40th Olympiad (I.3.2; 4.2.I). But later Polybius does return to defining the I40th Olympiad as his opening (tên arkhēn tēs heautōn suntaxeōs, 2.37.2; it is time for me to call to mind my original plan (protheseōs) and return to the starting point of my history (tēn arkhēn têes hautōn hupothesēos)', 3.5.9). Indeed, he even implies that there is no dispute over the temporal range of his story: 'The subject I have undertaken to treat, the how, when, and wherefore of the subjection of the known parts of the world to the dominion of Rome, should be viewed as a single whole, with a recognised beginning, a fixed duration, and an end which is not a matter of dispute' (3.I.4-5). In his epilogue, however, he adopts a slightly different perspective when he refers to this start as a 'fresh beginning' (palin ... arxamenoi, 39.8.6). Like Herodotus $(\rightarrow)$ and Thucydides $(\rightarrow)$, then, Polybius confronts the narratee with the problem of defining the start of the story. But Polybius handles the problem in a far more explicit and abstract way than his predecessors.

The same difference is seen in the way Polybius deals with the treatment of simultaneous events. Polybius sets out his principles in his narrative of the I40th Olympiad at the point where he moves from the Social War in Greece to events in Asia and Egypt. He explains that whereas in later Olympiads he adopts an annalistic method, with the narrative arranged by different geographical regions (and with those 
regions treated in a fixed order, with events in Italy first), for the I4oth Olympiad he treats in single units the events in the different areas (5.30.8-33).

Polybius brings out the reason for his change of ordering technique earlier in his work, when he synchronizes affairs in Greece with Hannibal's attack on Saguntum (4.28.I) and makes clear the lack of connexion between the two events: 'now had there been any connexion at the outset between Hannibal's enterprise and the affairs of Greece it is evident that I should have included the latter in the previous book, and, following the chronology, placed my narrative of them side by side in alternate sections with that of the affairs of Spain' (4.28.2). He explains that the sumploke- the interconnexion of events - did not occur until the third year of the I4oth Olympiad (4.28.5; cf. 5.I05.4-8 for the moment itself), but that he introduced synchronisms to make clear the chronological link between events ('merely recapitulating the contemporary occurrences set forth in the previous book', 4.28.6). His explicit comment at this point makes clear a point made by a number of other synchronisms found in his introductory books and in the main story before the sumploke itself occurs - namely that 'previously the doings of the world ... were held together by no unity of initiative, results or locality' (I.3.3-4). ${ }^{11}$

Towards the end of the History, Polybius anticipates the charge that his narrative is 'imperfect and disconnected' (atele kai dierrimmenēn, 38.5.I). He defends himself by appealing to the need for diversity felt by the sensory organs. Most thoughtful historians, he claims, have followed the lessons of nature and rested their readers with digressions. But while their digressions have been irregular and have left topics in the air, Polybius can claim that he has provided both diversity and regularity, thereby still enabling students to satisfy their desire for a continuous narrative $\left(38.5^{-6)}\right)^{12}$

One consequence of Polybius' chronological principle was that later events in one area were narrated before earlier events in another area

11 Other synchronisms: I.6.I-2; 2.44.2; 4.37.3-8, 66.8-10 (where Polybius notes that he had dealt with the synchronized matters 'in detail in my previous book, and now merely recall them to my readers in pursuance of my original plan that they may know what events were contemporaneous'); 5.I.3-5, I08.9-Io. Elsewhere there is a connection between geographically remote places, but the connection is not yet a global one (e.g. $2.29 \cdot 9-\mathrm{IO})$.

12 Cf. Meister i97 I on this passage. 
even when they followed causally from those earlier events. Polybius expressly confronts this feature of his work at $15.24 \mathrm{a}$, and later notes that it is a particularly common feature of his presentation of embassies (28.16.5-II, where he states that such reminders of the consequences of his method were frequent).

Polybius adverts to his maintenance of his chronological system by combining prolepsis with narratorial cross-references to the treatment of the events at the appropriate time, e.g. 'having, with the approval of Philip, made a foolhardy and ill-managed attempt to seize Messene, he perished in the action, as I shall narrate in detail (ta kata meros) when we reach that date' (3.I9.II; cf. 4.8I.I4; 5.I2.8 labontes ton oikeion kairon). He also uses the criterion of suitability when he promises a later treatment of Greek myths localized at the River Po (2.I6.I4-I5; detailed treatment about such stories is not suitable for the introduction). Similar signals that the narrative is sticking to a linear order are common in Diodorus (e.g. 2.31.2, 34.6; 5.3.6, 21.2; I4.63.2, I I7.6).

Polybius does not stick to his chronological principle consistently. The principle is broken when he groups together related events that took place in more than one year in the narrative of a single year. This is a common procedure in annalistic historians: it is the cause, for instance, of many of the chronological problems posed by Diodorus (cf. e.g. II.545-549 on the career of Themistocles). In itself this procedure is comparable to the common practice in non-annalistic historians of the explanatory analepsis and completing prolepsis; it only causes confusion when the departure from the annalistic structure is not marked out as such. Polybius is careful to note when he adopts this procedure and to justify his decision by explaining that the events would seem insignificant if narrated separately. One such occasion is his account of how Ptolemy IV Philopator took to a life of dissipation and late in his reign fought 'a war which, apart from the mutual savagery and lawlessness of the combatants, contained nothing worthy of note, no pitched battle, no sea-fight, no siege': 'It, therefore, struck me that my narrative would be easier both for me to write and for my readers to follow if I performed this part of my task not by merely alluding every year to small events not worth serious attention, but by giving once for all a unified picture so to speak of this king's character' (I4.I2.4-5; a note by the excerptor shows that this section went on for 48 pages). It is perhaps surprising that Polybius uses the adjective sōmatoeidēe ('unified': Paton's 'life-like' is wrong) of a section that breaches his normal rulesgiven that he applies the same adjective to the contents of his work as a 
whole (I.3.4) and compares reading the work itself to looking at a living animal rather than the dismembered limbs of a dead one (I.4.6-8; note the use of dierrimmena, the word put in the mouth of the detractors of his chronological system at 38.5.I..${ }^{13}$ Later Polybius notes that he has continued his narrative after the departure of Ariarathes from Italy until his restoration to power in Cappadocia, and then reverted to events in Greece, 'partly recurring to the past and partly anticipating the future, so that, the separate details of it being by no means striking, I may not by relating them under different dates, produce a narrative both obscure and insignificant' (32.II.I-6). Here Polybius has departed both from the normal ordering of events within the year (affairs in Greece were normally described between those in Italy and those in Asia) and from the annalistic framework.

Polybius also breaks the annalistic framework by the use of proleptic closure. Like Herodotus $(\rightarrow)$ and Xenophon $(\rightarrow)$, he looks ahead to the punishment of characters - but with a relish not easy to parallel in his more demure predecessors. When Philip V and Antiochus III agree to divide up Egypt, he looks ahead to their subjection to Rome, asking 'who among those who reasonably find fault with Fortune for her conduct of affairs, will not be reconciled to her when he learns how she afterwards made them pay the due penalty, and how she exhibited to their successors as a warning for their edification the exemplary chastisement she inflicted on these princes?' (I5.20.5). For Philip V he later expressly marks out 'the first outbreak of terrible misfortunes (deine tis arkhe kakōn)': '14 'it was now that Fortune, as if she meant to punish him at one and the same time for all the wicked and criminal acts he had committed in his life, sent to haunt him a host of the furies, tormentors and avenging spirits of his victims' (23.IO.I). In both cases anachrony is used to emphasize the workings of Tukhe. And in the second passage the departure from linear chronology is accompanied by another departure: Polybius abandons his historiographical principles and uses the sort of sensational and tragic language that he decries in other historians.

Prolepsis is used to particularly striking effect in Polybius' account of the early stages of the Second Punic War. Polybius alludes to Carthage's

13 Though note that the manuscripts are defective-but, as Walbank notes, the reading seems secure.

14 For the (Homeric, Herodotean, and Thucydidean) phrase arkhe kakōn, cf. also I8.39. I and 22.I8. I (again of Macedon). 
defeat when he explains the causes of the war: he tells how Hannibal's father made him swear as a boy never to be friend of the Romans - and justifies the anecdote by revealing that Hannibal told it to Antiochus when he had taken refuge at Antiochus' court (3.II). Again, in calculating the distance covered in Hannibal's march he mentions that a certain part of the road has 'now been carefully measured by the Romans and marked with milestones at every eighth stage' (3.39.8-looking ahead a century to the construction of the Via Domitia in ri8). But the most significant prolepsis occurs right at the end of the third book. The chronological structure adopted for the I40th Olympiad allowed Polybius to offer a unified treatment of the Second Punic War up to the Battle of Cannae in a single book. He also heightened the sense of Rome's desperate position by looking beyond Cannae and mentioning the surrender of Tarentum (3.I 8.3), even though that only occurred in 213, three years after Cannae (but not expressly marked out as proleptic). Polybius increases the sense of the Romans' hopeless position to make their response to disaster the more impressive:

the Senate neglected no means in its power, but exhorted and encouraged the populace, strengthened the defences of the city, and deliberated on the situation with manly coolness. And subsequent events made this manifest. For though the Romans were now incontestably beaten and their military reputation shattered, yet by the peculiar virtues of their constitution and by wise counsel they not only recovered their supremacy in Italy and afterwards defeated the Carthaginians, but in a few years made themselves masters of the whole world.

(3. $118.7-9)$

With astonishing speed Polybius has moved from one of the Romans' worst defeats to their position of global domination - the central theme of his narrative.

Polybius' use of internal prolepsis in the account of the Second Punic War is revealing of the forward momentum of his work. None of his three predecessors ( $\rightarrow$ Herodotus, $\rightarrow$ Thucydides, $\rightarrow$ Xenophon) stated at the outset the end result of his work. When Polybius defines his work at the start, by contrast, he looks ahead to Rome's unparalleled subjection of almost the whole world (I.I.5). The same teleology informs his decision to give a summary of the contents of the work at the start of book 3 .

Polybius' internal analepses vary greatly in scope and extent and in the contexts in which they are introduced. As in Herodotus, they may be used to underline breaches of reciprocity, with a strong moral tone (e.g. the repeating analepsis at I.8o.I2). When the Achaean Alexon 
helps Carthage by some timely news, Polybius introduces him as a man 'who had on a former occasion saved the Agrigentines' (I.43.2), and then repeats this information ('Alexon, who had previously saved by his loyalty not only the city and district but the laws and liberties of Agrigentum, now was the cause of the Carthaginians being saved from total ruin', I.43.8). As we have seen, this is not the only time that events with an Achaean connection are privileged.

Longer analepses are often marked out as such by an overt signal (most commonly (pros)anadramontes) and used to give background about a city or person. As we have seen, Polybius introduces at the start of his work a brief account of Roman history before the crossing to Sicily, stating that he will occasionally 'go back in time to add some of the earlier history of the most famous states' (I.I2.8; prosanatrekhōmen tois khronois) later in the work as well. That brief account of Roman history has the same explanatory function as the sketches of the immediately preceding events in Egypt and Syria introduced before the account of the war over Coele-Syria fought between Antiochus III and Ptolemy (note the analeptic markers at 5.31.8 (brakhu prosanadramontes) and 5.40.4 (anadramontes): these analepses go back to the period covered in the two introductory books, where Polybius explicitly noted that he was omitting Asian and Egyptian history). Later, when Polybius introduces Philopoemen, he defends the principle of giving the earlier history of characters as well as details of the foundations of cities (I0.2I.23 , presumably referring both to foundations included in works and to whole works devoted to foundations).

Polybius tends to employ a summary form in these explanatory or scene-setting analepses. The summary (kephalaiōd $\bar{e}, 5.40 .4)$ account of Antiochus' reign aligns it with the introductory books, while the summary form is used for Philopoemen's background because Polybius had already written a separate biography of Philopoemen (I0.2 I.7).

Analepses are especially common in Polybius' frequent didactic and argumentative sections. In his treatise on the art of generalship (9.I220), for instance, he condemns Nicias' refusal to leave Syracuse owing to an eclipse of moon (9.I9.I-4), while in a discussion of treachery (I8.13-I5) he at first claims that he will not 'draw examples from far-off times' but 'from the very circumstances we are dealing with' (I8.13.7), but soon moves on to a critique of Demosthenes' views of treachery in the De Corona (I8.I4). Sometimes his technique is to give parallel instances (e.g. 8.35, followed by an explicit moral in 8.36; 9.8, 23) or to draw contrasts (e.g. Philip V's savage sack of Thermos stressed by 
contrast with examples of previous Macedonian moderation such as Alexander's sparing the temples in his sack of Thebes, 5.9-Io).

Typical of Polybius is the use of analepsis in the course of his polemics against earlier historians. Book $\mathrm{I} 2$ is devoted entirely to such polemic and includes discussions of the treatment of battles by Callisthenes and Ephorus. Similarly at 8.10-1 I a discussion of Philip and Alexander follows criticism of Theopompus' treatment of them. At times Polybius assesses suitable topics for historians with moral and patriotic criteria that recall the strictures of Dionysius of Halicarnassus in his criticism of Thucydides: at 7.7.7-8 Polybius complains about sensational accounts of Hieronymus and says that historians should write about the thirdcentury rulers Hiero and Gelon instead (a brief account of their lives follows), while at $15 \cdot 34-35$ the same point is made with reference to the Egyptian regent Agathocles (historians should write about the Sicilian Agathocles). Most intriguing, perhaps, is the passage where Polybius points out inaccuracies in the works of Zeno and Antisthenes of Rhodes (16.I4-20) - and reveals that he wrote a letter to Zeno pointing out his mistakes (i6.20.6-9).

Scholars have examined Polybius' many and varied references to the past in order to discover his historical perspective. ${ }^{15}$ What emerges from detailed analysis is that there are relatively few references to the fifth century or earlier. Polybius pays most attention to the fortunes of the Greek cities from the fourth century onwards and to the Macedonian royal house. The Persian Wars of the early fifth century are, however, important for understanding Polybius' placement of his own fabula in relation to the past. As he approaches his climax, he magnifies the disasters suffered by the Greeks in 146 by reviewing their earlier misfortunes from the Persian Wars on and concluding that the disasters he is about to describe were the greatest ever (38.2).

By contrast with the wealth of external analepses that Polybius employs to bring out his political and moral messages, there are few external prolepses in Polybius - even though Polybius himself seems to have lived at least until is8. It was not, of course, in Polybius' power to narrate events subsequent to his own time-but he did shape his narratee's historical understanding with several hints of the future.

Polybius displays his powers of foresight when he describes the silting caused by the influx of rivers into the Pontus (Black Sea): 'when a

${ }^{15}$ Cf. Millar i987; Lehmann I989-1990; Walbank 2002: 178-I92. 
period has elapsed which stands to the time it takes to fill up the Palus Maeotis in the same proportion as the cubic capacity of the larger basin to that of the smaller, the Pontus will become, like the Palus Maeotis, a shallow fresh-water lake' (4.42.4). Here the flow of water from the Palus Maeotis out towards the Ocean mirrors Polybius' view of historical causation, with one war leading on to another $(3 \cdot 32.7) .^{16}$ At the same time, Polybius is evoking two earlier historians: Herodotus and Thucydides had shown a similar power to look into the distant future when discussing the silting caused by the Nile and the Achelous (Hdt. 2.I .4; Th. 2.102.3).

Polybius also looks to the future when he outlines his cyclical view of constitutional change in book 6 . He argues that it was the Romans' mixed constitution and their military practices that enabled them to recover from Cannae. But he also speaks of the 'change for the worse which is sure to follow some day'-for Rome 'will undergo a natural decline' (6.9.I2-I4). The relation of Polybius' circular view of constitutional change in book 6 (the anakuklosis) to the rest of his account is a notorious problem: according to Momigliano, "when he came to historical narrative, he forgot cycles'. ${ }^{17}$ But the organic view of decline that is expressed in book 6 is one with great resonance in the rest of the History.

Hints of Roman decline are strongest in two actorial prolepses, ${ }^{18}$ one placed near the end of the work as originally planned, the other near the final end of the work. In the first passage, Polybius quotes a passage from Demetrius of Phalerum's prose work on Fortune. Demetrius had written that fifty years previously neither the Persians nor the Macedonians would have believed that Macedon would have crushed Persia: 'But nevertheless Fortune ... who always defeats our reckoning by some novel stroke ... now also, as it seems to me, makes it clear to all men, by endowing the Macedonians with the whole wealth of Persia, that she has but lent them these blessings until she decides to deal differently with them' (29.2I.5-6). Polybius, pondering the downfall of Perseus, reflects that 'this utterance of his seems to me to have been more divine than that of a mere man' (29.2I.9). Once more it is the extraordinary workings of Fortune that disrupt Polybius' annalistic scheme. And the

${ }^{16}$ Cf. Clarke i999: I26.

17 Momigliano 1977: 189.

18 There are also many actorial analepses in Polybius: cf. my remarks at $S A G \mathcal{N}$ I:I60-I62, with bibliography cited there. 
temporal dislocation - an analeptic account of a pessimistic proleptic vision - may lead the narratee to reflect that Fortune could well treat Rome just as she had just treated Macedon. ${ }^{19}$

The second prolepsis of Rome's downfall comes at the fall of another enemy, Carthage:

After being wrapped in thought for long, and realizing that all cities, nations, and authorities must, like men, meet their doom; that this happened to Troy, once a prosperous city, to the empires of Assyria, Media, and Persia, the greatest of their time, and to Macedonia itself, the brilliance of which was so recent, ... Scipio said, 'A day will come when sacred Troy shall perish, and Priam and his people shall be slain'.

$(38.22 .1)$

Scipio's tears evoke Antiochus' tears towards the end of Hieronymus' history, ${ }^{20}$ while the general stress on mutability also looks back to Herodotus' reflection that cities once great were now small and that cities now great were once small (I.5.4) and to Thucydides' anticipation of Athens and Sparta as ruins (I.IO.2). At the same time, while the historians agree that all things decline, there is no way of knowing when decline will set in. For Polybius, as for Herodotus and Thucydides, the possibility of calculating the development of a natural process such as silting contrasts with the difficulty of foreseeing the human future.

The passages where Polybius shares a long-term perspective with his predecessors are, however, isolated. For the most part, he shows vastly more awareness of chronological issues, repeatedly drawing on an abstract theoretical vocabulary drawn from rhetorical writers. In his handling of time, as in so many other ways, Polybius adopts the stance of the professional-not least to conceal the political.

19 Paton makes Perseus subject of the opening sentence of the section: 'so then often and bitterly did Perseus call to mind the words of Demetrius of Phalerum' (29.2I.I). If that is right, then Perseus' bitter recollection is parallel to Croesus' belatedly recalling Solon's wise words (Hdt. I.86). But Walbank I957-I979: ad loc. objects that 'neither the text nor probability offers any justification' for this.

${ }^{20}$ J. Hornblower i98I: I04-106. 